Article

\title{
The Survival of Andalusi Artistic Formulas in the Time of Hernan Ruiz I
}

\author{
Ángeles Jordano \\ Department of Art History, University of Córdoba, 14071 Córdoba, Spain; ajordano@uco.es
}

Received: 15 June 2018; Accepted: 1 August 2018; Published: 9 August 2018

\begin{abstract}
In the transition from the Middle Ages to the Modern Era, Hernan Ruiz I worked as master builder of the Cathedral of Cordoba. His works exemplify the adoption of an artistic language resulting from the symbiosis of Gothic, Renaissance and Islamic formulas. In this paper, we demonstrate the imprint of the Andalusi aesthetic in this master's work. Through an analysis of his building works and the evolution of his style, we show that Hernan Ruiz I's legacy is more important than what historiography has previously suggested, which has only addressed the transition in his architectural style from Gothic to Renaissance and has overlooked the impact of Andalusi formulas in his work. Hernan Ruiz I bore witness to an important change in the mentality and aesthetic tastes of his time, and although his son, Hernan Ruiz II, gained greater recognition for his work, his father was able to adapt a church model imbued with the medieval spirit to the demands of the new patrons, namely the nobility and high clergy. These clients imposed their tastes, which were anchored in the past, but were open to new Renaissance influences due to their humanistic training and, at the same time, attracted by the exoticism and prestige of Andalusi art.
\end{abstract}

Keywords: Mudejar; architecture; master architect; church; Cordoba; Hernan Ruiz I's burial

\section{Introduction}

At the turn of the fifteenth to the sixteenth century, marked by the transition from the Middle Ages to the Modern Era, the master architect Hernan Ruiz I, also known as the Elder (1479?-1547), was active in the city of Cordoba, Spain. This article aims to contextualize his building works with a view to understanding the important role he played in the passage from medieval to modern architecture, and how the Andalusian influence (Islamic tradition in the ancient al-Andalus) endured in his work through the use of certain elements that merged with other elements of Christian origin. It supposed the constitution of a great example of architectural hybridization that is still surprising today (Burke 2010; Dodds et al. 2008). The powerful image of the Mosque of Cordoba defined the following constructions inside it, such as, for instance, the Royal Chapel (Ruiz Souza 2006), which resulted from the great exchange of cultures.

His homonymous son, Hernan Ruiz II the Younger, is much more well known, mainly due to his treatise on architecture, his successful intervention in the Giralda bell tower of the Seville Cathedral and other outstanding works. Most of these works are documented, as has also occurred with his son, Hernan Ruiz III.

Hernan Ruiz I may have been less studied than his descendants because his work is not as widely documented. We do not intend to carry out an in-depth analysis here, but rather to undertake a task we owe to this master, and which historiography has tended to overlook, attracted more by the brilliance of his descendants. In their classic study of Hernan Ruiz II the Younger (Banda y Vargas 1974), A. de la Banda y Vargas provided some biographical data on Hernan Ruiz I and briefly mentioned some historical and artistic aspects of this master's works. For his part, M. Nieto Cumplido provides additional information on his origins, carries out a historical and artistic study of San Juan Bautista 
Church of Hinojosa del Duque, Cordoba (Nieto Cumplido 1982), and provides a detailed account of the master's role in the construction of the chancel, transept and choir of the main church of Cordoba, the Mosque-Cathedral (Nieto Cumplido 1998). Although some more recent works have analyzed Hernan Ruiz I's career from a technical perspective (Gimena Córdoba 2016, 2015, 2014, 2011; Ampliato Briones and Córdoba 2014), our aim is to offer a concrete vision of the imprint that the Islamic tradition left on his work; an aspect we consider to be of utmost importance in order to fully understand the enduring effect of Al-Andalus culture in the centuries following its disappearance (Urquízar Herrera 2017).

To begin, we will give a brief overview of the most important biographical data of this master architect. Son of Gonzalo Rodríguez-a stonemason who died before 1508-and Maria Ruiz, both old Christians, Hernan Ruiz I had among his brothers Juan Ruiz, also a stonemason, which reveals the tradition of the trade in the family. His date of birth is unknown, although A. de la Banda notes that he may have been born in 1479 (Banda y Vargas 1974). In 1508, he married his second wife, Catalina Sanchez (or Ximenez or Fernandez), with whom he had seven children, the firstborn being Hernan Ruiz II. Another of his sons was Juan Ordoñez, prebendary of the Cathedral of Cordoba, to whom we will return later.

In 1504, Hernan Ruiz I became a member of the builders guild and just ten years later was already master builder of the Cathedral of Cordoba, as well as of the city's works. He died in early September 1547 and was buried in the cathedral's transept (Banda y Vargas 1974), although the exact place had not been determined (Nieto Cumplido 1982, 1998).

He worked both in the city and in numerous towns of the province. His intervention in the Mosque-Cathedral of Cordoba reveals his desire to harmonize the Andalusi and Christian artistic language (Figure 1a). To do so, he employed what was perhaps the most extended formula at that time in Spain, combining elements of the Islamic tradition with Christian styles and which had begun to be used with great success in the fourteenth century in the former Umayyad capital of Al-Andalus. The mark left by more than five centuries of Muslim rule from 711 to 1236, the year when the city was incorporated into the Crown of Castile by Ferdinand III, was so profound that its aesthetics continued to be intertwined with other Christian artistic styles that drew from the Islamic tradition those elements that best matched the tastes of the time (Feliciano and Ruiz Souza 2017; Feliciano and Rouhi 2006). Thus, while in the fourteenth century latticework took center stage, from the fifteenth century and especially from the sixteenth century onwards it was wooden carpentry, particularly for the construction of spectacular ceilings, which became the fashion and expanded this Islamic influence throughout Spain and Latin America practically until the present day. Although some argue that this trend ended in the sixteenth century, we have strong evidence that it continued until the eighteenth century, and that by the nineteenth century Islamic architectural elements were revived and reinterpreted and survive even today, with workshops recovering drawings, techniques and materials or seeking inspiration in existing ones to give birth to new creations.

\section{Hernan Ruiz I's Intervention in the Mosque-Cathedral of Cordoba}

Although the work of Hernan Ruiz I has been studied using a variety of approaches, whether formal, historical or architectural, our intention is to show, above all, the apparent ease with which the master architect combined the solutions handed down from centuries of Islamic building experience with the advances of late Gothic architecture (especially the stellar vaults) and the Renaissance influences imported from Italy.

It is interesting to observe how in the new chancel, built inside the original Aljama Mosque after 1523- "an intervention that Christianizes completely the building" (Urquízar Herrera 2003)—following a well-known controversy between the cathedral chapter and Bishop Alonso Manrique, the driving force behind the project (Nieto Cumplido 1998), Hernan Ruiz I dedicated his efforts to constructing Gothic vaults in order to create a luxurious ensemble along the perimeter of the Latin cross floor plan that marked the new intervention (the chancel, transept and choir) (Figure 1b). 


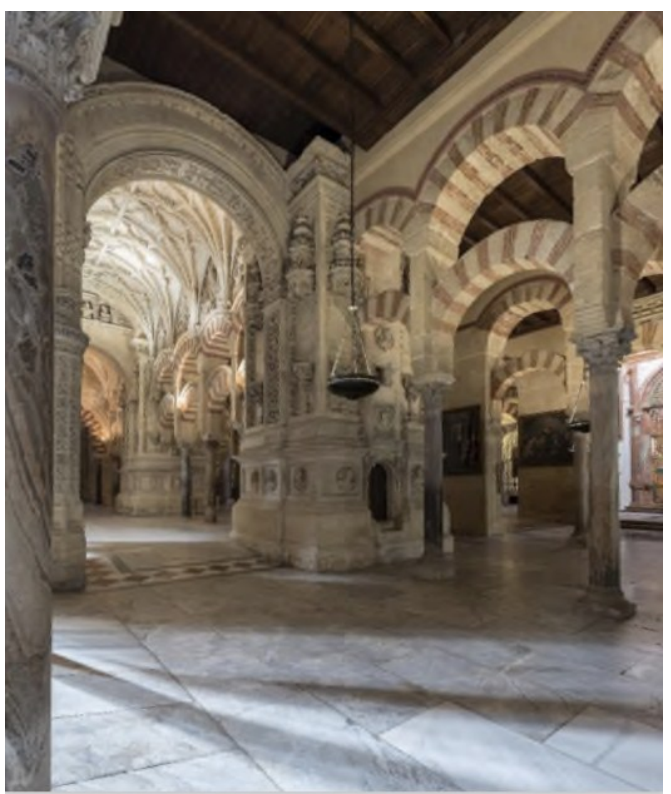

(a)

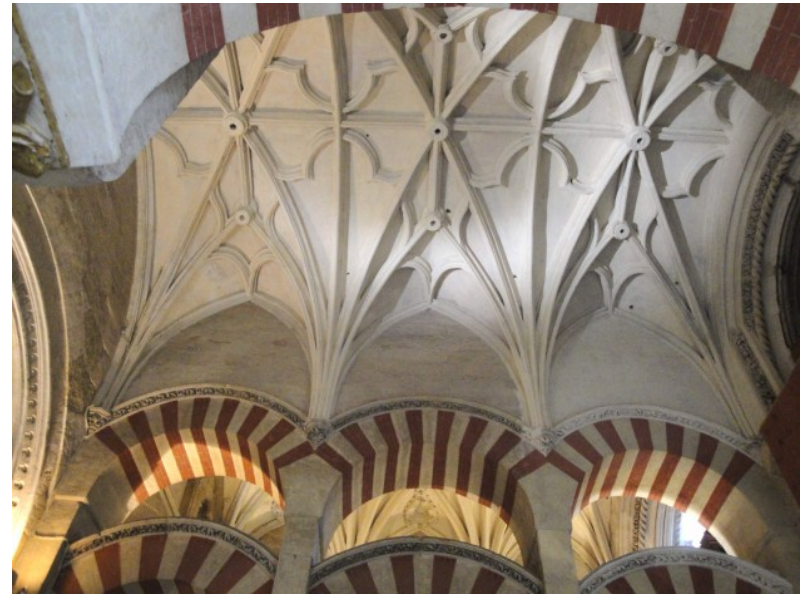

(b)

Figure 1. Hernan Ruiz I. Mosque-Cathedral of Cordoba: (a) Transition from Abd al Rahman I's naves to the Christian nartex. (C) Cabildo Catedral de Córdoba; (b) stellar vaults in the perimeter of the Latin cross. Photo took by author.

In contrast, however, he achieved a perfect symbiosis in the walls between the pre-existing Umayyad Caliphate arches - which he took advantage of to design the tracery-by combining the Islamic arrangement of small blind arches of the sebka type with the typologically Christian shape of the pointed or trefoil arches (Figure 2a). In addition, the elevation of the east and west sides, with their triple arcades sheltered by a semicircular relieving arch, is reminiscent of the basic structure of the Ambassadors hall in the Alcazar of Seville.

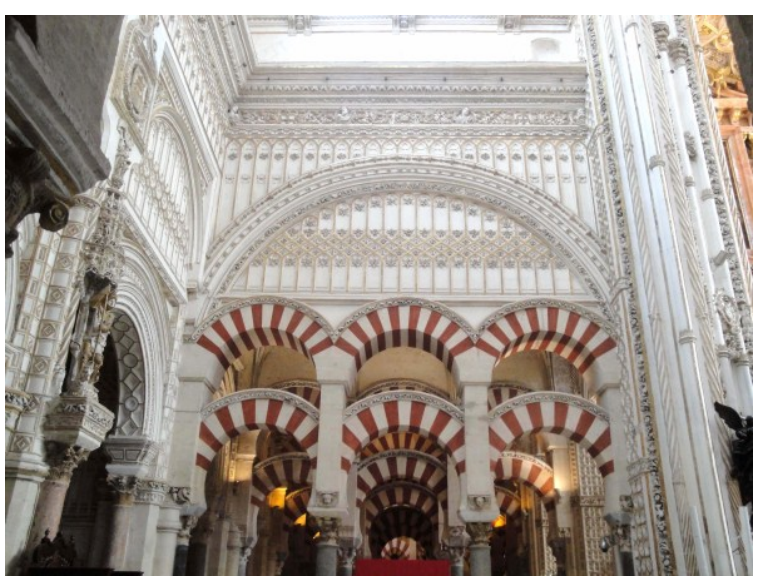

(a)

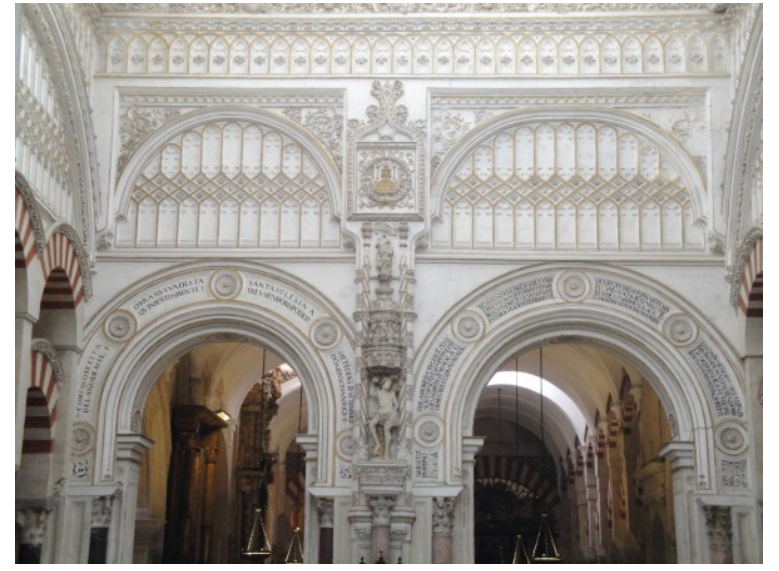

(b)

Figure 2. Hernan Ruiz I. Transept. Mosque-Cathedral (Cordoba): (a) East side; (b) South side. Photos took by author.

Moreover, on the north and south sides of the transept, he not only overlaps the arches, but also emphasizes the superior arches by using a drip cup with Christian plant motifs in the spandrels (Figures $2 \mathrm{~b}$ and 3). He finalized the caliphal inspired structure with a frieze of blind arches, a solution that had already been used in the San Sebastian gate of the mosque, and that major achievement was 
the façade of the mihrab. Consequently, the sources of inspiration for the master seem obvious, to which he also greatly contributed.

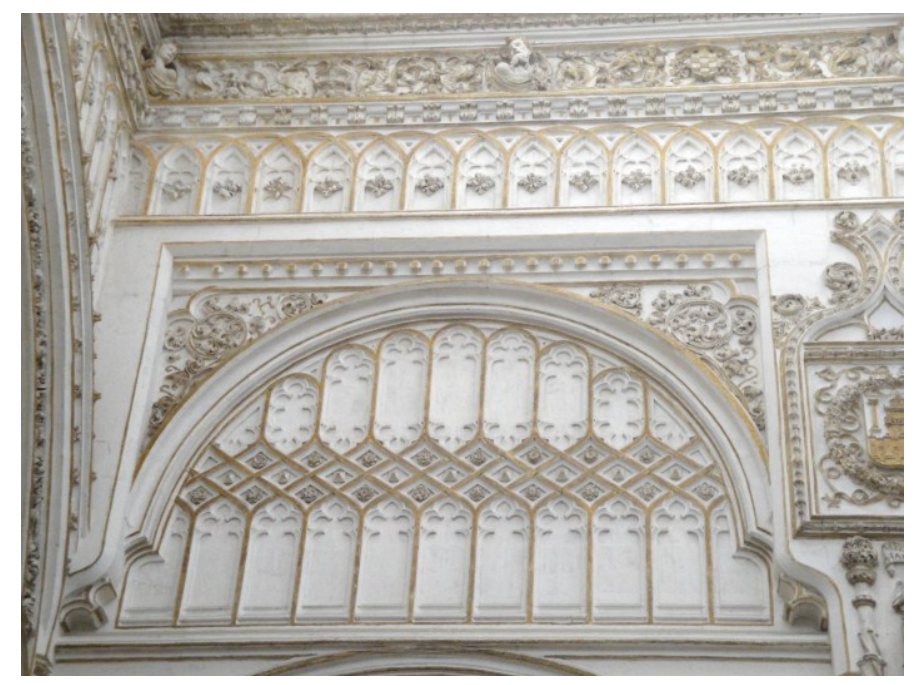

Figure 3. Hernan Ruiz I. Transept. Mosque-Cathedral (Cordoba). Photo took by author.

The way in which Hernan Ruiz I closes the chancel towards the Islamic prayer room with an ornate net of subtle arches that seems to imitate the forest of columns is similarly interesting (Figure 4).

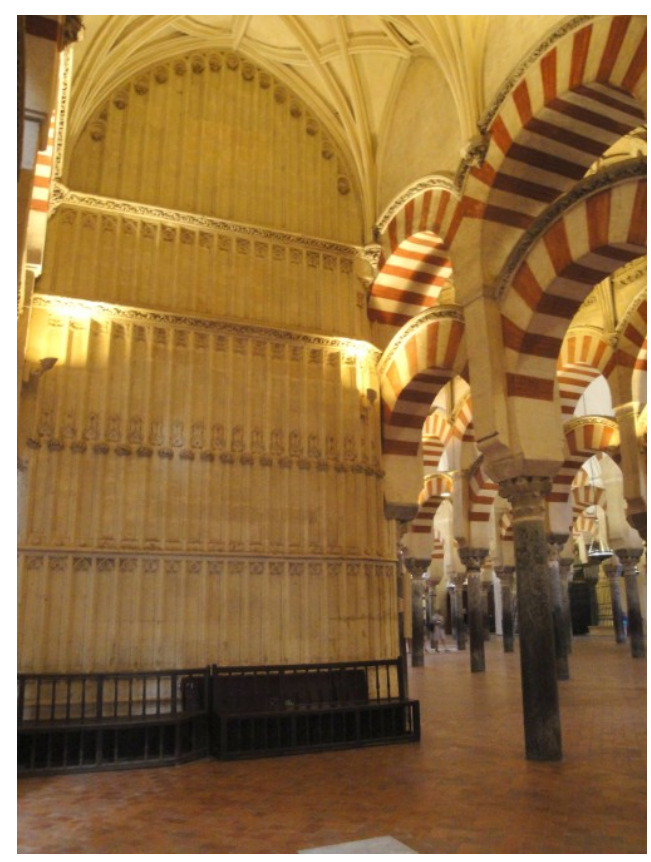

Figure 4. Hernan Ruiz I. Exterior of the chancel to the South. Mosque-Cathedral (Cordoba). Photo took by author.

In contrast, the tenacity with which Hernan Ruiz I constructed the Gothic vaults surrounding the central cross is astonishing. Upon closer examination, however, it becomes apparent that the creation of a sequence of stellar vaults built upon the Caliphate columns and arches was the most practical and obvious way of ensuring that the new Christian construction would stand out. It was a pragmatic solution, since it would surely have been a daunting challenge to replace the old supporting structures with new ones. 
Thus, his intervention was aimed at inexorably imprinting the Christian seal on the enclosure, which, on the other hand, marked a clear difference between the new liturgical space and the old Islamic one in a more visual way. In doing so, the processional walkway was perfectly distinguishable for the canons and marked the way to the cross of redemption that stood symbolically in the center of the Muslim prayer hall (Moreno Cuadro 2007) (Figure 5).

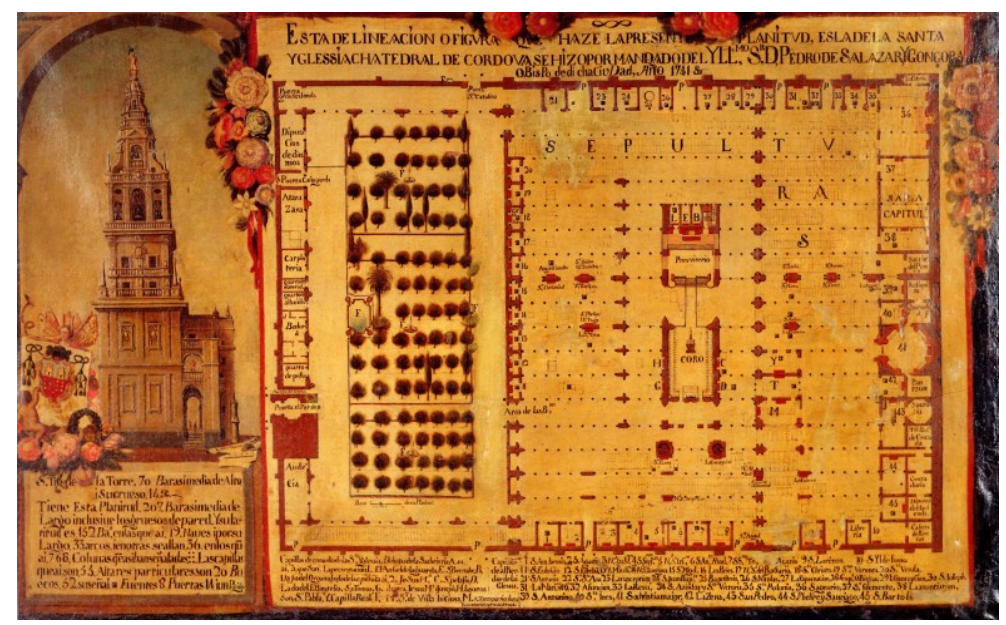

Figure 5. Current floor plan of the Mosque-Cathedral. 1741. (c) Cabildo Catedral de Córdoba.

If the impression of a nineteenth-century traveler such as Gautier was that "Cordova has more of an African look than any other Andalusian city", to such a point that he claimed "if the Moors were to return, they would not have to alter much before settling down" (Sumichrast 1912), then it would not be surprising that this perception was much stronger in Hernan Ruiz's time due to the countless buildings from previous eras that must have remained standing. Although Gautier was very critical of the chancel, transept and choir, he acknowledged the fine work of Hernan Ruiz:

This parasitic church, a monstrous stone mushroom, an architectural wart which has grown on the back of the Arab building, was constructed from the designs of Hernan Ruiz, and is not without merit in itself; anywhere else it would be admired [...].

Despite his harsh words, Gautier described the cathedral as being "one of the most marvellous buildings in the world" (Pardo Rodríguez 1989). In addition, although he reproached the alterations made to the mosque, his recognition of the Christian construction suggests that Hernan Ruiz had put enormous effort into integrating the different styles. This, as we pointed out, can be seen in the way in which the Caliphate arches in the lower parts were used to provide a Christian ascent that culminated in the great vaults of Gothic design and Renaissance ornamentation built by his successors (Figure 6).

The gallery of arches of the Orange Tree Courtyard in the Mosque-Cathedral is the other intervention which reveals this syncretism between Islamic and Christian elements. Although the courtyard's authorship has not been certified, the evidence seems to indicate that it may have been the work of the master's hand. The round stilted arches resting on columns with Arab capitals framed by a drip-cap offer an evocative image that speaks of this perfect ensemble of elements of diverse cultural origin, which blend together elegantly (Figure 7). It is a widely accepted formula employed in various types of works (San Sebastian and Anton Cabrera hospitals, Santa Clara Church, the Santa Marta and Capuchin cloisters, the portico of the Casa de las Campanas, etc.). What is striking about the solution adopted by the master in the courtyard of the Mosque-Cathedral is the way he incorporated Christian elements in the drip-cap, which he emphasized with a series of moldings, among which a thick reed one stands out. This formula was also used in the San Miguel door located on the west wall of the enlargement made by Abd al-Rahman II, in which the coat of arms of Bishop Juan Daza (1504-1510) is displayed. We believe that it is an example that perfectly illustrates how a former door 
of the Mosque was Christianized by means of a drip-cap (Jordano Barbudo); an element that would be widely employed in this type of intervention. Indeed, in the architecture of the Pedroches, an area in the north of the province of Cordoba, these drip-caps would continue to be a recurring feature almost until the present day. It is possible that the formula was devised by Hernan Ruiz I for the Orange Tree Courtyard and, given its acceptance, was widely used.

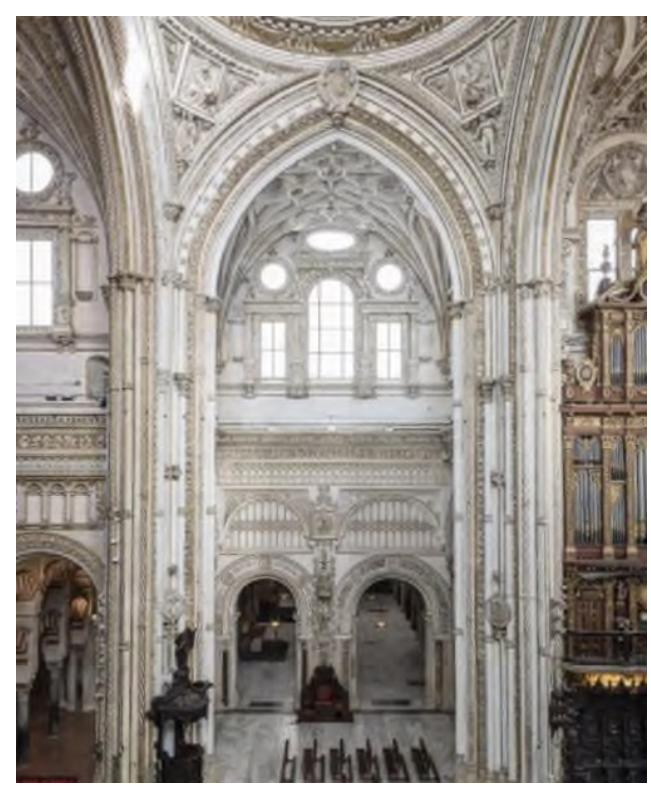

Figure 6. Hernan Ruiz I. Transept. Mosque-Cathedral of Cordoba. (c) Cabildo Catedral de Córdoba.

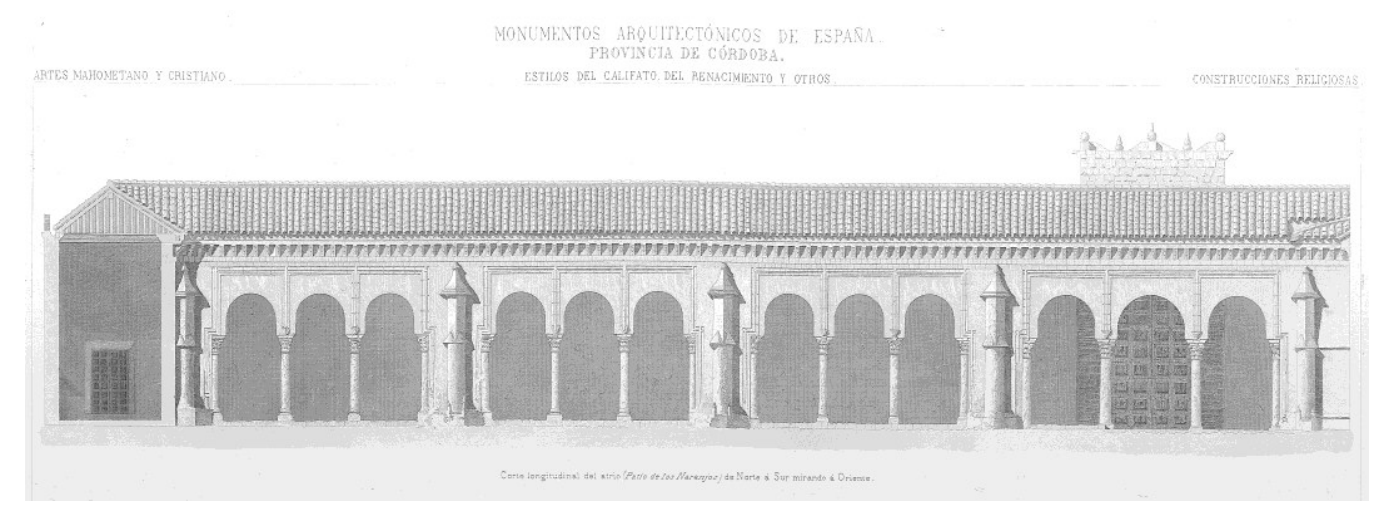

Figure 7. Orange Tree Courtyard. Mosque-Cathedral of Cordoba (B. Arredondo. E. Buxó, secciones (Amador de los Ríos and Amador de los Ríos y Villalta 1879).

\section{Hernan Ruiz I and the Consolidation of the Parish Model}

The parish church model that was imposed at the end of the thirteenth century in Cordoba and served to erect the first Christian temples in the conquered city had a layout consisting basically of three naves and a triple apse. These churches incorporated few Islamic elements, as it seemed that the Christians wanted to visually symbolize the supremacy of the new religion and therefore limited the presence of Andalusi features. Although it is not our intention to address this question here, as it has already been studied on other occasions (Jordano Barbudo 2002), it is revealing that Hernan Ruiz I, master builder of the Cathedral of Cordoba and visitator of the bishopric-a figure that was responsible for overseeing the existing buildings in the province belonging to the Diocese of Cordoba-maintained the model that had been used systematically since the thirteenth century, although he adapted it to fit in with the new aesthetic trends. The fact is that the churches built in the time of Hernan Ruiz I 
maintain the same floor plan mentioned above, but with some changes. The one that most singularly affects the topic of this study is the evolution of the wooden ceilings parallel to the construction of the Gothic vaults covering the apse. Indeed, while the latter displayed an increasingly elaborate ribbed design with a greater number of additional decorative elements and were more complex than the simple ribbed vaults of the thirteenth century, the carved and pictorial decorations of the wooden ceilings also increased in complexity.

With regard to the carved wooden ceilings, it is important to mention their geometrical decorative elements, such as carved hexagonal (alfardones) and lobed (chillas) pieces, which are decorated with paintings. However, the tie-beams are also made more complex through the use of stars that often stand out for their beauty and size. The muqarnas ornaments resembling stalactites or honeycomb gain in sumptuousness and are usually gilded. The girder and other supporting parts of the frame are now richly painted with plant motifs interwoven with bright colors. In addition, there are heraldic motifs and even calligraphic inscriptions, sometimes in Latin, but more often in Kufic Arabic script.

Thus, the model that had been used since the conquest to build the first churches belonging to the religious orders of the Dominicans (the Real Convento de San Pablo, 1241) and Franciscans (San Pedro el Real, ca. 1241) was consolidated. Hernan Ruiz was receptive of this model and brought it to its height in examples such as the parish church of San Juan Bautista in Hinojosa del Duque, which was completed by his son Hernan Ruiz II and Juan de Ochoa (Figure 8).

This example shows the evolution with respect to the original model because, among other reasons, the double arcade of the Cistercian church which had been one of the characteristic elements of the Cordoban parish church model, was simplified. Although clearly based on this model, it was stylized in line with this new interpretation. The almost generalized pointing of the upper arches (which are not quite round) and the disappearance of the robust cornice on which the framing rested in the city's churches contributed to this. The ceiling, on the other hand, is more elaborate. As we mentioned, the boards are more richly carved and are decorated with a great variety of plant, geometric, epigraphic and sometimes heraldic motifs.

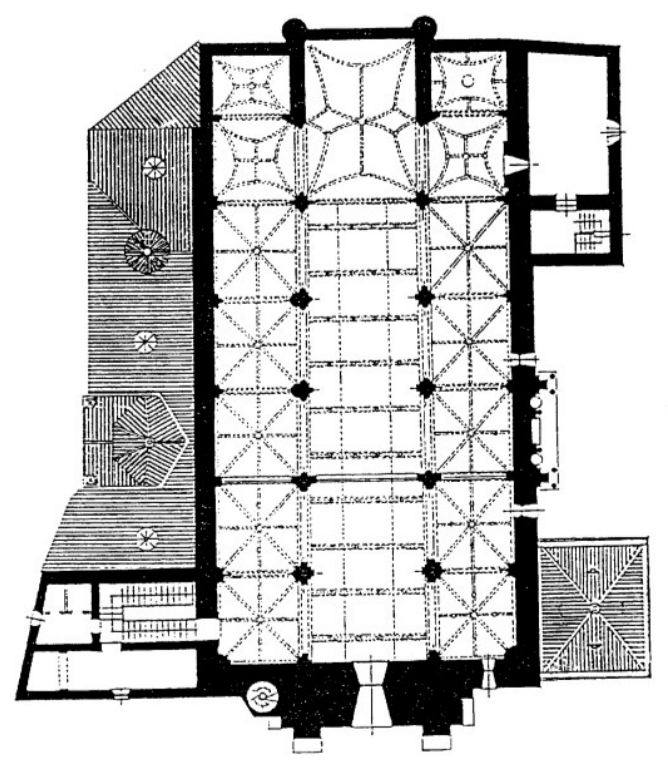

(a)

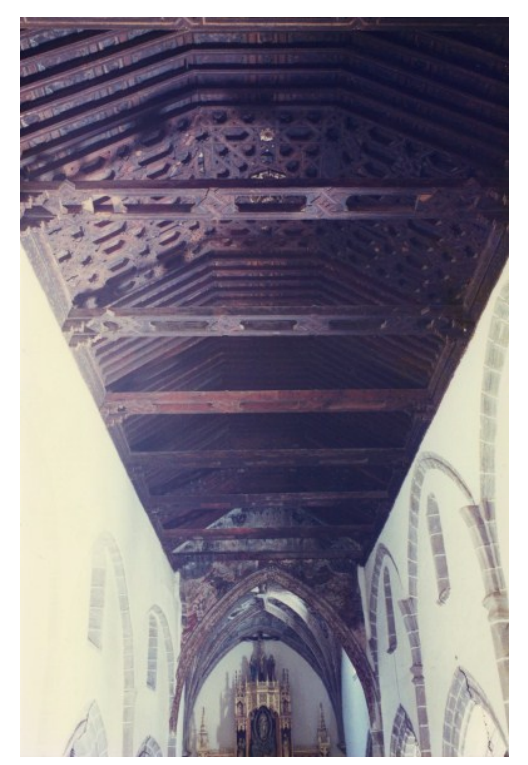

(b)

Figure 8. Parish church of San Juan Bautista. Hinojosa del Duque (Cordoba): (a) floor plan. ( Junta de Andalucía; (b) wooden ceiling of the central nave. Photo took by author.

What warrants including this example of San Juan Bautista is that it reveals how the master builder's style took a turn; a change that would contribute to the survival of an architectural scheme more in line with the Islamic tradition. The fact is that at one point, the building plans for the temple 
were modified. In the beginning, the church was designed to have vaults along its entire length, but there was an easily perceivable modification. The supporting structure and height of the arches vary. Even on the epistle side, the arch springers that were intended to withstand the thrust of the vaults of the central nave were removed because the project was brought to an end. Instead of the Gothic vaults that were originally meant to cover the nave, a wooden collar-beam ceiling was installed. We do not know why this change occurred, but can assume that the building tradition, the fact that the workers were skilled in the construction of these ceilings, the prevailing taste, and perhaps some other reason that escapes us were more important factors than the master's attempt to build a completely vaulted church, because the fact is that the choir and the area under the choir loft (sotocoro) are also covered by ribbed vaults with tiercerons. This question is crucial, because it would determine the future development of the Cordoban parish model. Nor can we say that the change occurred here, since the use of stone rather than wood for the temple ceiling seems to be justified in Hinojosa, which is located in the Pedroches, an area traditionally rich in granite; hence, we can assume that the material was, in principle, affordable.

It is not difficult to see that this model was quite widespread and reached new heights, as evidenced in the construction of Nuestra Señora de la Asunción of Dos Torres, a town near Hinojosa, although the church dates back to a later period. The coat of arms of Bishop Martín de Córdoba y Mendoza was displayed in the chancel, so it is dated between 1578 and 1581 and can be attributed to Hernan Ruiz III (Nieto Cumplido).

The old town of Pedroche, where the church dedicated to the Transfiguration of the Savior was erected, is not far from here. The church has not been attributed to any master, but it is in the same typological line that we have described above, and it would not be surprising if it were designed by Gonzalo Rodríguez and perhaps concluded by his son, since the coat of arms of the Catholic Monarchs after the incorporation of Aragon (1479) can be found in the choir.

This is another example of the consolidation of the parish model, although in this case the Islamic imprint is perceived in a more visible way. The octagonal piers are of a characteristic Mudejar type that was common precisely under the Catholic Monarchs. At least that is what we have identified in the case of Cordoba. Moreover, the pointed arches are framed by drip-caps, which is uncommon in churches of this type, and there are oculi instead of windows above the arches. However, perhaps the most remarkable aspect of these churches is the presence of wooden carpentry, which, apart from the collar-beams, also included a wooden choir decorated with paintings and supported by curvilinear corbels of Andalusian inspiration. The parapet is decorated with eight-pointed star latticework, but the most extraordinary feature is the combination of motifs of Islamic origin-including inscriptions in Neski-with purely Gothic motifs, such as thistle leaves, which also decorate the ceiling. The boards of the ceiling have carved alfardones and chillas embellished with leaf motifs typical of the Islamic and other Gothic styles; a style that is also represented by the flamboyant tracery with Almohad motifs, such as the intertwined octagons. The connection that shows this rich decoration with the singular ceilings of the convent of Santa Clara de la Columna in Belalcazar, another of the nearby towns, indicates that crews of artists must have moved from one place to another in search of patrons and building works. It therefore seems evident that the same workers would have been hired by the Counts of Belalcazar to build the aforementioned convent. In fact, the flat ceiling with latticework (taujel) in the baptistery of the parish church of Pedroche is very similar to the ceilings found in Santa Clara since, like the convent, it is decorated with a rope motif alluding to the Franciscan Order (Jordano Barbudo 2002).

Unlike the architecture of Pedroches, with its characteristic grey granite, further south in the province in the town of Montoro it is the reddish-colored stone which lends a distinctive mark to the architecture. The parish church of San Bartolomé gives us the opportunity to see first-hand the image through the visitator general's eyes. Let us not forget that Hernan Ruiz himself was a visitator general, and although he may not have intervened directly in this work, he at least left his signature on it. The chancel, with its three vaulted chapels with Gothic tiercerons, originally displayed the coat of arms of 
the bishop of Cordoba, Bro Bernardo de Fresneda (1572-1577). However, given the late date of his episcopate (much later than the time of Hernan Ruiz I), his coat of arms may have alluded to some reform of the church, since the vaults would have been very archaic at that time. What is interesting here is the visitator's description of the church contained in his report:

He also visited the material body of said church, which had three naves built of carved millstone from barbers' shops with good bases without carvings or moldings. The chancel was made of the same carved stone. The stone-vaulted ceiling with moldings and ribbons with their pine cones, gold mouldings and the coat of arms of the good Bishop Bernardo de Fresneda, and on the apse ends of the side-aisles there were two other chapels with stone vaults with moldings and ribbons without mouldings. The roof of the main nave was made of carved pine wood with a latticed pattern decorated with gold pine cones, and the ceilings of the side-naves were of wooden beams and brick [...] (Nieto Cumplido).

As this text indicates, another beam and brick system was widely used, which in the case of San Bartolome was reserved for the aisles. It is important to recall that in the cloister of San Sebastian Hospital, located just across from the Mosque-Cathedral of Cordoba, this type of enclosure was also used to cover the galleries of the courtyard; a work that has been attributed to Hernan Ruiz I. Vestiges of this system can also be seen in the Anton Cabrera Hospital and the Capuchin and Santa Cruz cloisters, among others. Clearly, it was a simpler structure, but also with striking results, since the surface of the brick that was left exposed was usually painted with plant, geometric and even epigraphic motifs of either Islamic or Christian influence (flamboyant stencils, for example).

Although not documented, it is assumed that Hernan Ruiz I oversaw the building works of Nuestra Señora de Soterraño, the parish church of the town of Aguilar de la Frontera, which replaced the previous church, which was too small to accommodate the population (Luque et al. 1981) (Figure 9). This work marked the beginning of the master's turn towards the new architectural styles coming from Italy. However, was this of his own making, or was the mind of a humanist behind him? It has been said that Catalina Fernandez de Cordoba, II Marchioness of Priego and wife of Lorenzo Suarez de Figueroa, Count of Feria (Nieto Cumplido 1984), was responsible for commissioning the works. In his extensive study of the counts of Feria, Rubio Masa states that the library of Lorenzo III Suarez de Figueroa (1505-1528) housed 284 volumes, including many by Italian humanists (Rubio Masa 2001). It should be noted that his palace in Montilla was connected by a passageway to the convent of Santa Clara; a work in which, as we have said, the master also intervened. At that time, Montilla was the capital of the count's seigneury and included, among others, the villa of Aguilar.

Up to this time, there had been a process of integration that merged elements of Islamic inspiration with the Christian ones of Gothic architecture, but the time had come to usher in the Renaissance, and it is these new airs that can be perceived when entering Soterraño Church. Although the model is the same as that of the first churches built after the Christian conquest, these constructions are more diaphanous, which is achieved by means of slender piers; a perception that the visitator general of the bishopric of Cordoba expressed in his report when he described the church as being "of good foundation and talent, grand and well finished" (Nieto Cumplido). The church of San Mateo in the town of Lucena was built in the same style, and although later than Soterraño, it was also commissioned by another of the most powerful lineages of the Kingdom of Cordoba, which, like the previous ones, belonged to the great House of Cordoba: the lords of Chillon, Espejo and Lucena, who would be granted the distinction of Marquises of Comares.

In both cases, the staggered triple-apse arrangement and diverse floor plans (hemicycle, polygonal, straight or alternating) characteristic of the first period were substituted for an apse end consisting of three flat chapels laid out in a line, as in the case of Soterraño, or a somewhat deeper central chapel, such as that of Lucena. In both examples, it is clear that the aim is to make the space as uniform as possible to achieve a visual perception of transparency.

In Aguilar, the ribbed vault of the chancel is divided into eight webs, and the keystone bears the coat of arms of the Fernandez de Cordoba family. In contrast to this archaic roofing, it is important 
to highlight the segmental triumphal arch, which was a new development. In the same way, the molding of the vault, the piers on which it rests, and the smaller capitals mark this trend towards simplification to achieve a sensation of openness. A similar assessment could be made of the naves, whose piers suggest a change in plans. However, without a doubt, what is most worthy of mention in the assimilation of Andalusi formulas is the collar-beam wooden ceiling of the main nave, where the corbels supporting the tie-beams display the classicist acanthus leaves, thus indicating the contribution of the new Renaissance styles. Far from lessening the splendor of these wooden ceilings, they are better resolved, technically, through the use of more complex solutions (Figure 10). The tie-beams, for example, are decorated with double latticework patterns that create stars of considerable size, such as those to be found in the Animas Chapel of the Asuncion Church in Santaella.

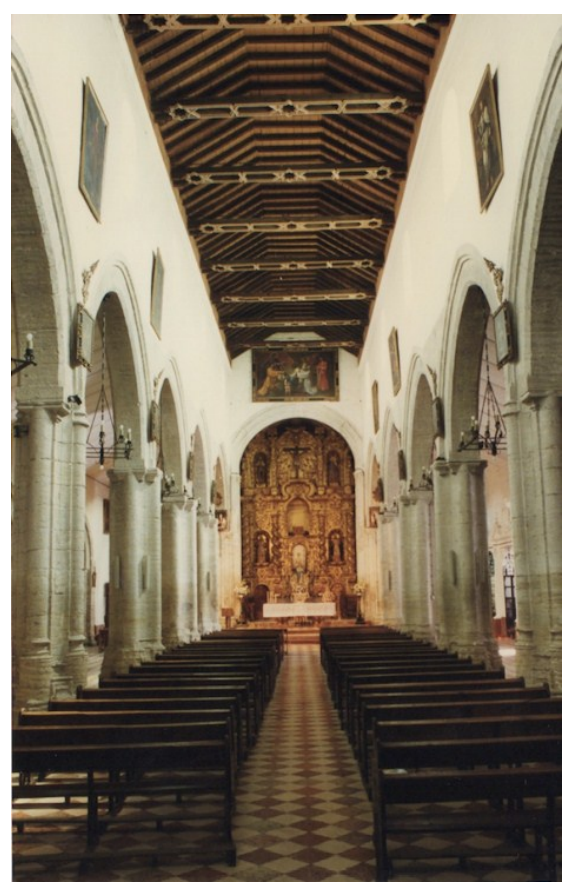

Figure 9. Parish church of Santa Maria del Soterraño. Aguilar de la Frontera (Cordoba). Photo took by author.

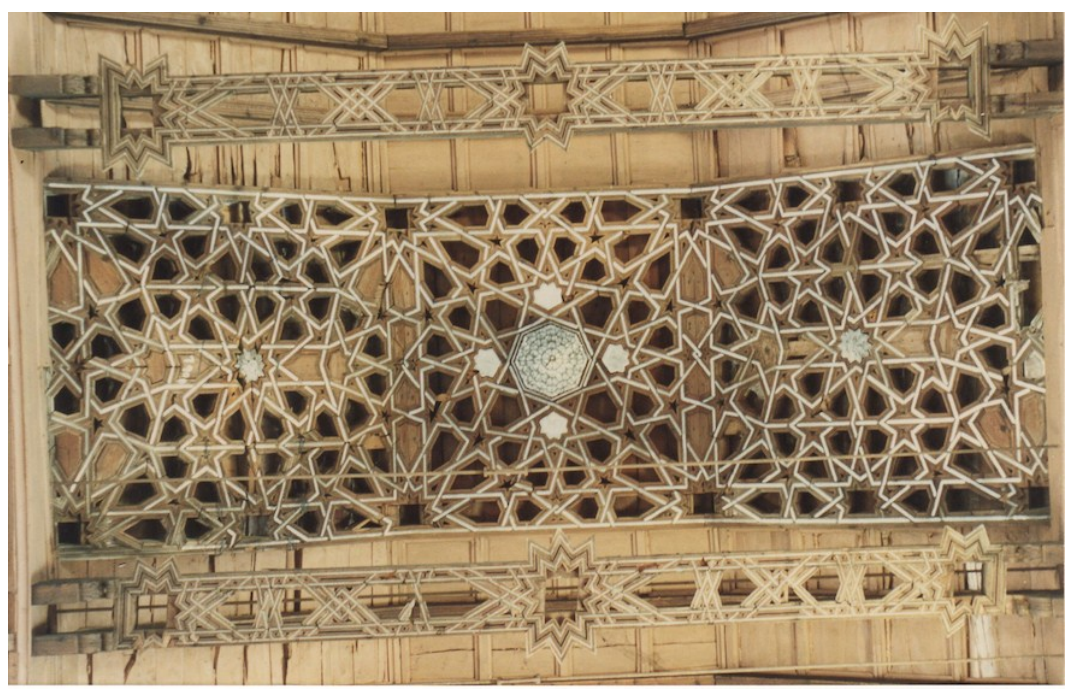

Figure 10. Detail of the wooden ceiling. Parish church of Santa Maria del Soterraño. Aguilar de la Frontera (Cordoba). Photo took by author. 
The San Mateo Church of Lucena may be considered the final link in the evolution of the parish model during Hernan Ruiz I's time (Figure 11). That this church was built at a later date (the end of the fifteenth or beginning of the sixteenth century) could be due to the fact that elements recovered from the Lucena's aljama or Great Mosque were used in its construction, as had occurred in Cabra, for example, and perhaps also due to its proximity to the border with the Nasrid Kingdom of Granada. The Christian victory at the battle of Lucena in 1483, with Boabdil imprisoned, must have been another important reason. The new work, which was undertaken following the demolition of the previous construction in 1498, was made possible thanks to the patronage of Diego Fernandez de Cordoba, I Marquis of Comares, and whose son Luis continued later.

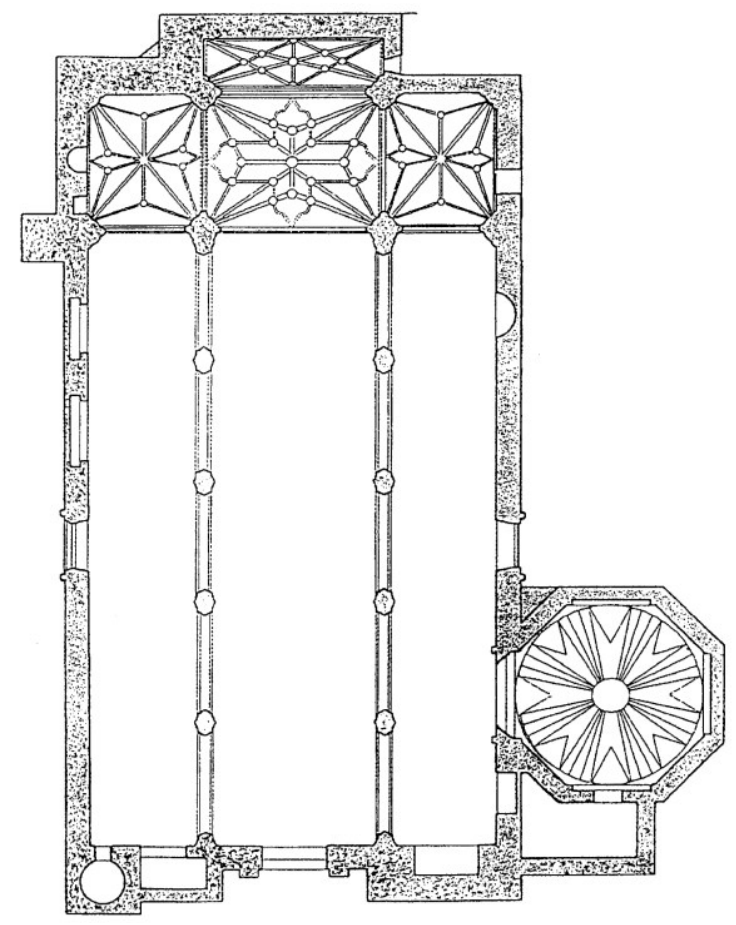

Figure 11. Floor plan. Parish church of San Mateo. Lucena (Cordoba). (C) Junta de Andalucía.

The model of the first parish churches of Cordoba underwent a substantial change, as can be seen in the notable increase in their diaphanous space as described above. This was achieved through the use of simple, slender piers, now with small, unadorned capitals, but also by elevating the arches and building naves of equal height, which lent these churches a very similar appearance to that of the hall churches inspired in the German hallenkirche (Figure 12). We must also add another factor that differs from the other examples analyzed here: the use of a drip-cap on the wall-ribs; a feature that may be attributable to the closer proximity to Islamic territory. Following the pattern of previous cases, the naves were covered with wooden ceilings, the central one being of the collar-beam type, and the apse end was designed with three straight chapels, the central one of which projects out a bit from the rest. The vaults are all stellar, although they became increasingly complex in their design and number of ribs. This may be due to the fact that in the last decade of the sixteenth century the chapels were sinking, which forced the Count of Pradas to authorize a payment of 74,592 maravedis in order to "build the three chapels of the church, the chancel and the side chapels" (Nieto Cumplido).

The lateral portals of the Virgin and San Miguel have been attributed to Hernan Ruiz I. They were also built using the same scheme and with a similar drip-cap. It is a pity that the inner doorway that leads to the sacristy has been torn down. It seems that the round arch may also have had a similar drip-cap, as the first springers would seem to indicate. If this were the case, the entire ensemble would have perfectly combined these influences, as the decorative program could not be more Christian with 
the coat of arms of the Marquises of Comares bearing the fesses of the Cordoba lineage-the chained head of Boabdil and the flags that were won from him flanked by two lions-while the molding that forms the drip-cap is decorated with thistle and animal motifs, thus displaying an image of power and propaganda.

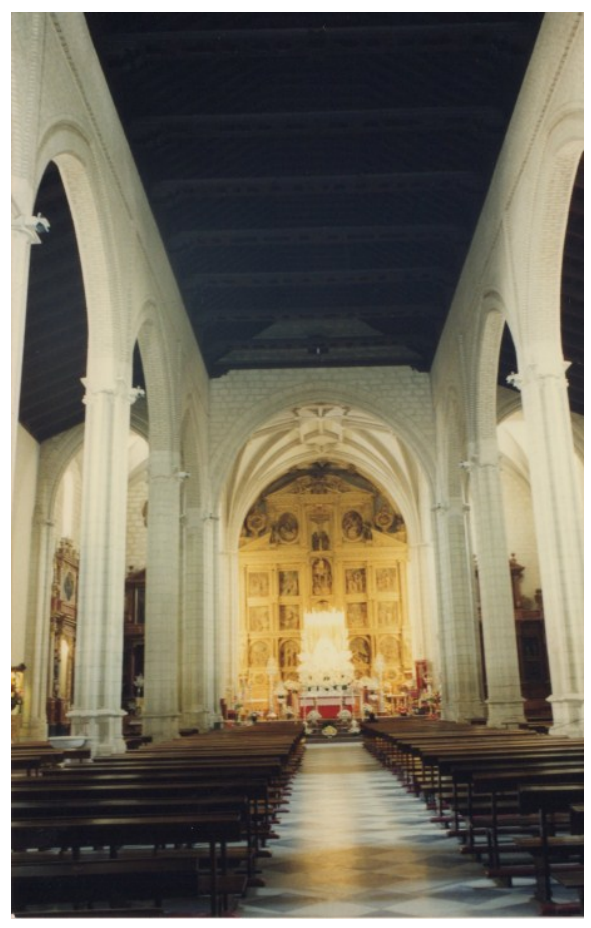

(a)

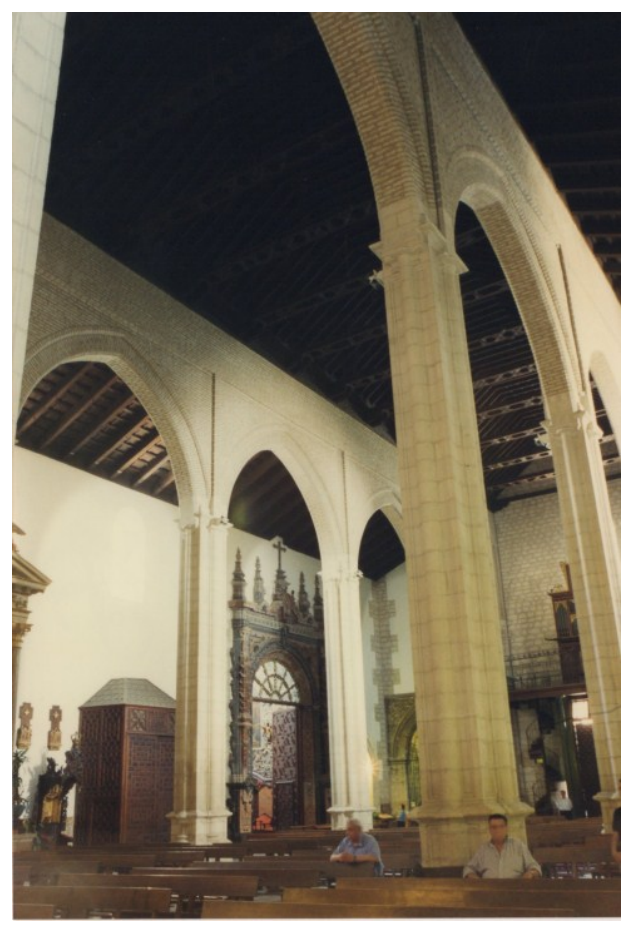

(b)

Figure 12. Parish church of San Mateo. Lucena (Cordoba): (a) central nave; (b) wall-ribs. Photos took by author.

This portal of the sacristy is a perfect example of what we are attempting to transmit, here, because, in our opinion, it reveals the aesthetic trends of a society transitioning from Medieval to Modern times in the passage from the Gothic to the Renaissance, with a still-notable Islamic presence of the former Al-Andalus, which was now Christian. Logically, the mentality of the master, in this case Hernan Ruiz I, was also changing, and in attending to the demands of a humanistic-minded clientele, he laid the foundations for the subsequent arrival of Renaissance styles. For this reason, even though he may not have achieved the fame of his son Hernan Ruiz II, he was able to adapt to the changing tastes of his clientele. After the initial phase of the Reconquest, when the first parish churches had been built thanks to the administrative organization of the dioceses (only the conventual temples of San Pablo and San Pedro el Real were commissioned by the king), Hernan Ruiz I was prepared for what would come later: the almost complete control over building undertakings by the nobility and even the ecclesiastical dignitaries. This enabled them to convey the propaganda of their lineage using heraldry to gain notoriety, while patronage was a form of atonement and a way to ensure a privileged place of burial in the churches they themselves had commissioned to be built.

\section{The Box Floor Plan of Female Conventual Churches}

The other model that was characteristic of Hernan Ruiz I's work was the box floor plan typical of convents; that is, a rectangular layout which was adapted perfectly to the needs of the nuns and their promoters since it allowed the nuns to attend liturgy, either from the choir and sotocoro, or through the rood screen of the main altar, while it also provided a place for the founders to be buried, usually in the chancel. This model was first used in the Monastery of San Juan de los Reyes of Toledo, which 
was commissioned by the Catholic Monarchs. Perhaps the earliest example in Cordoba is that of Santa Marta, a Hieronymus monastery where Hernan Ruiz I's sister took the name of Sister Maria de San Miguel upon professing her vows, and whose church appears to have been founded circa 1479 by their father, Gonzalo Rodriguez (Banda y Vargas 1974). The formula is very simple: the chancel is covered with Gothic stellar vaults and the nave with ridge-ribbed vaults, although the choir originally had a wooden ceiling painted with shields, of which two boards are preserved in the cloister's vestibule. These are the only remains that survived after this part of the high choir was restored in the twentieth century and a false ribbed vault was installed.

In 1480, the chancel was not yet finished, but seven years later the first Counts of Cabra were buried there. However, it is likely that the work was not completed until the first decade of the fifteenth century. The portal is dated 1511 and is the work of Hernan Ruiz I (Banda y Vargas 1974). It should be noted that the late Gothic-style portals in the city-the first of which was this example of the Hieronymus monastery-underwent a clear evolution (Santa Marta, San Andres, San Jeronimo and San Sebastian churches), especially this one of Santa Marta (Figure 13a) and that of San Sebastian Hospital, where the master erected an ogee arch decorated with foliage, clusters flanked by savages-one playing a horn and the other holding a rope (Figure 13b)—and tracery spandrels embellished with small arches and a type of drip-cap reminiscent of a brief roof (tejaroz). The characteristic feature is that the surface of this drip-cap, which is constructed from two piers that flank the portal, is adorned with tracery in the form of intertwined arches resembling the Almohad sebka. These elements led A. de la Banda to describe them as "faint but certain Mudejar influences" (Banda y Vargas 1974). The formula is repeated again in San Sebastian Church, although with later solutions and an obvious taste for what is traditionally known as the Plateresque style. This system of Christianized drip-cap and elaborate spandrels with a network of arches is the same one that Hernan Ruiz I would use in the Cathedral transept some years later. Thus, it could be inferred that Santa Marta and San Sebastian were his 'testing grounds' with regard to this particular feature, although the master may have built other works with this same formula that have not survived.

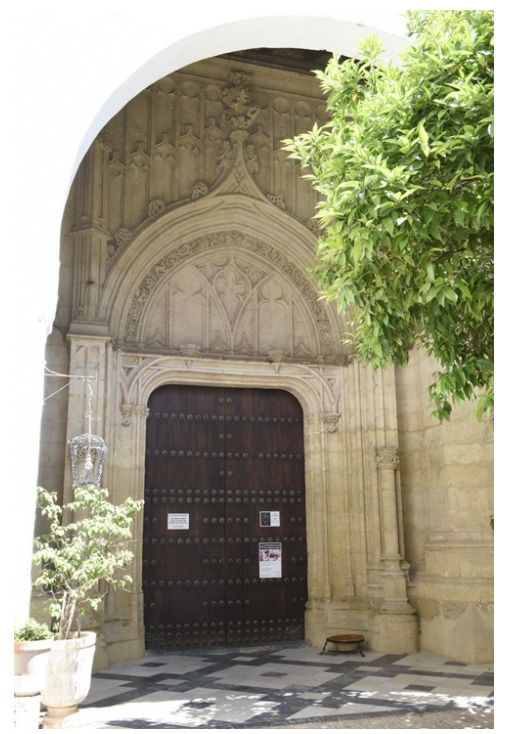

(a)

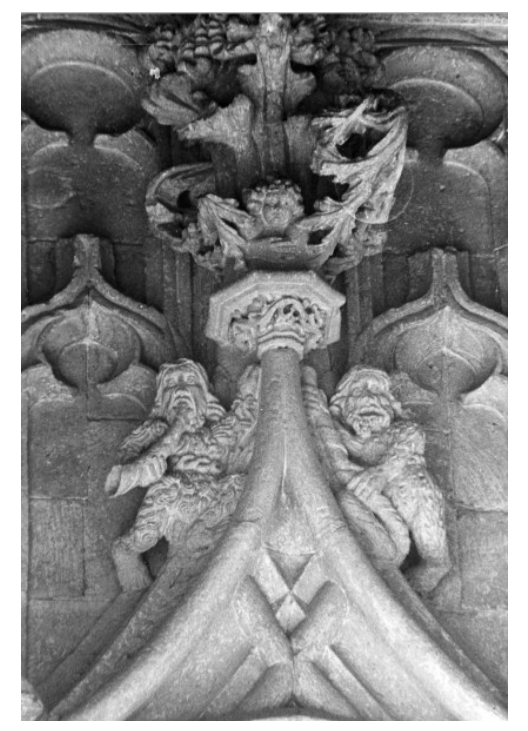

(b)

Figure 13. Santa Marta Monastery (Cordoba): (a) church portal; (b) feature of the high point of the ogee arch. Photos took by author.

The persistence of Islamic elements is most noticeable in the Santa Clara Convent of Montilla, whose façade has been attributed to the master and is dated after 1525. The piers flanking the church portal are again topped by a drip-cap, this time without tracery. The wooden doors, on the other hand, are decorated with latticework. The chancel is covered with an octagonal wooden ceiling 
with an assembled, geometric latticed pattern, while the ceiling of the nave is constructed of paired beams. The eight-strand latticework extends over certain elements, such as the tie-beams, in which large stars stand out. It is a model that would become very popular throughout the province, and of which notable examples still survive, such as the parish church of Nuestra Señora de Guadalupe in Baena, whose founder was Pedro Fernandez de Cordoba, son of the Third Count of Cabra, or Santa Clara Church of Palma del Rio, in whose chancel the First Counts of Palma were laid to rest (Gamero Ruiz et al. 1994). Another example is Madre de Dios in Baena, a Dominican convent that must have been built around that same time (Figure 14). Although the conventual church underwent major alterations that transformed its original image, its heraldic tiles (housed today in the Instituto Valencia de Don Juan) continue to bear witness to the ever-present Islamic imprint, as well as the Mudejar flooring of the temple, made with scraps of tiles (Figure 15), or the taujel of the porch that precedes the portal, where the coat of arms of its founder, Diego Fernandez de Cordoba, III Count of Cabra and Lord of Baena, is displayed. The count founded the convent so that his daughter, Juana de la Cerda, born to his wife Francisca de Zuñiga y la Cerda, could act as prioress (Jordano Barbudo 2002).

However, the Santa Clara Convent of Montilla is paradigmatic in this sense. Not only is there a tribune above the chancel where the Marquises of Priego could attend the services, but also an elevated passage over the street connected to their palace which provided direct access to the church (Casado Alcaide and Jordano Barbudo 2010).

It is very revealing that the simple nave and chancel model in which the spaces are not architecturally distinct (Gimena Córdoba 2015), the first example of which is probably Santa Marta, is more similar to Christian formulas due to the ribbed-vault ceilings. However, from that time on, there was a tendency to use the Islamic-style wooden ceilings, which were of a quality and opulence comparable to that of the Christian vaults. Moreover, the individual covering of the chancel, which was also separated by means of a triumphal arch, lent this part of the church greater autonomy. This scheme was a reinterpretation of the Islamic qubba system; that is, a construction with a square floor plan that symbolized the earthly versus the celestial, represented in this case by a domed wooden structure sprinkled with stars (e.g., Guadalupe Church in Baena, Jesus Crucificado Hospital in Cordoba).

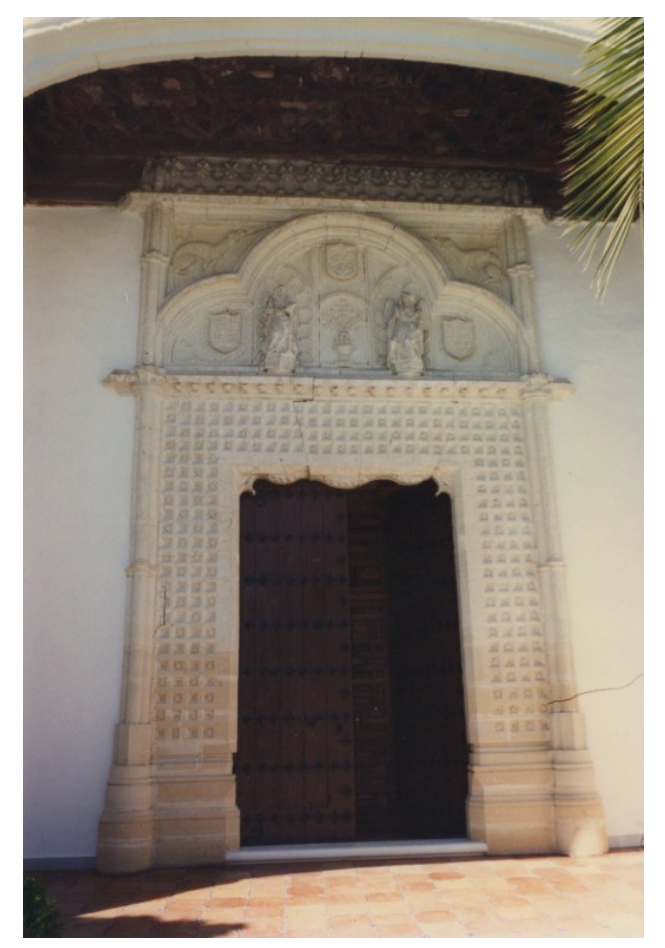

Figure 14. Portal. Madre de Dios Convent. Baena (Cordoba). Photo took by author. 


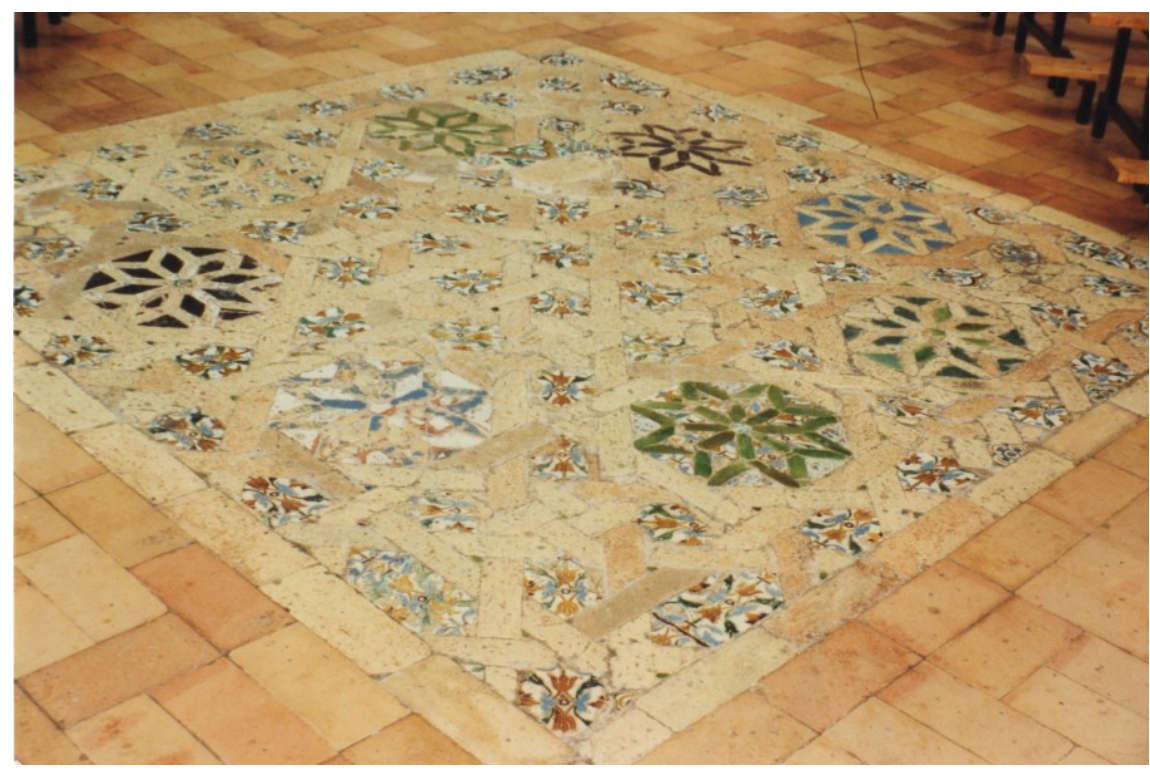

Figure 15. Brick and tile flooring. Madre de Dios Convent. Baena (Cordoba). Photo took by author.

It is also important to point out that this style, in our opinion, was probably not cultivated only by the master builders. The patrons of these works, especially in the conventual foundations, were noblemen who demanded this type of miscellaneous art simply because it was the fashion of the time, and not only because it lent them prestige, but because of the exoticism this aesthetic could have had for a Christian. One only has to see how, in 1487, the Second Count of Cabra ordered in his will that he be buried alongside his parents in the chancel of Santa Marta Convent, that the nuns be given the tunic of Boabdil—whom the Count had taken prisoner in the battle of Lucena (1483) — to make a chasuble, and that the flags he won be placed on his father's tomb (Abad de Rute 1958, 1961; Nieto Cumplido).

\section{Epilogue. The Death of Hernan Ruiz I and His Burial in the Mosque-Cathedral of Cordoba}

In his work La catedral de Córdoba, M. Nieto Cumplido states that Hernan Ruiz must have died in early September 1547, because on the 6th of that same month his widow engaged in litigation over the will. According to one witness, she attended the death of the master builder and his burial in the city's main church. Nieto posits that he might have been buried with his son Juan Ordóñez, the prebendary of the cathedral, under one of the two arches on the south side of the transept. Indeed, it is here where a tombstone bearing his shield can be found. It reads: AQVI ESTA SE/PULTADO/IOAN ORDO/ÑEZ RECIO/NERO DE ESTA/SANTA IGLE/SIA FALLECIO/A 26 DE DICI/EMBRE AÑO/DE 1606 ${ }^{1}$ (Nieto Cumplido 1998).

The chronicle of M. Medina González, published in the Diario Córdoba newspaper of 9 March 1943, in which he refers to the discovery by Enrique Romero de Torres of Hernan Ruiz I's remains in this burial place, confirms that this is the where master lies (Figure 16a). Romero de Torres, driven by his innate curiosity, located the will of Juan Ordoñez dated 6 November 1604. As prebendary of the Cathedral Church of Cordoba, he said:

When God our Lord is served by my paying this natural debt and I am deceased, my will is that my body be buried in the Cathedral Church of Cordoba, in the tomb I have in said church, where Hernan Ruiz, my father, master builder of said holy church, is buried, which is under an arch of one of the side chapels of the new transept where there is a marker that tells when the new work was begun.

\footnotetext{
1 Here lies Ioan Ordoñez prebendary of this holy church deceased the 26th of December in the year 1606.
} 
After receiving the pertinent authorization Enrique Romero de Torres had requested from the Cathedral Chapter, and under the direction of the architect Felix Hernandez, the tomb was opened and a burial vault was found which had been carved into the stone of the foundation of an arch. The burial vault contained the remains of two bodies facing east mixed with earth, wood debris, leather, fabric and lace. In the center, on the body of the son, appeared the skull of Hernan Ruiz I surrounded by bones.

The remains were placed in a new brick and cement burial vault, along with a copper plate indicating the date they were found. Afterwards, the ledger stone of the prebendary was put back in its original place, as we can see it today (Figure 16b). In the arch beneath which this ledger stone is located, there is an inscription dedicated to the work of his father Hernan Ruiz I: "He began this new work of this Holy Cathedral Church on 7 September 1523, the bishop being Alfonso Manrique" (Figure 2b).

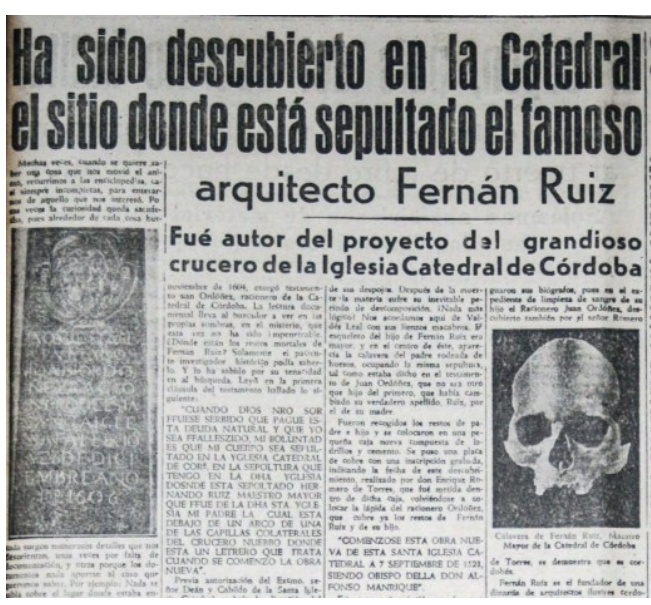

(a)

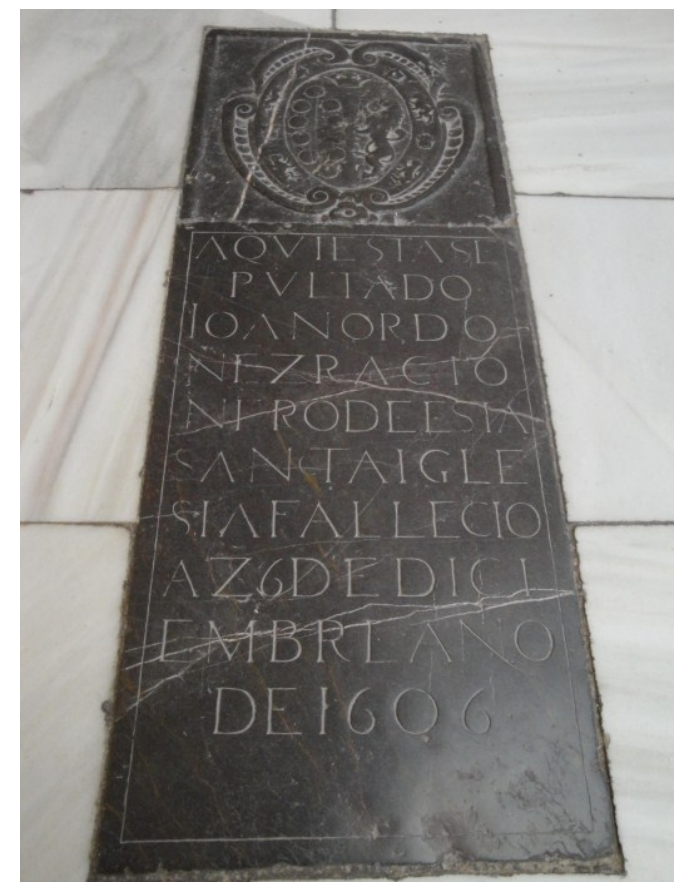

(b)

Figure 16. Juan Ordoñez and Hernan Ruiz I's burial. Mezquita-Catedral (Cordoba): (a) piece of news; (b) tomb. Photo took by author.

The desire of the prebendary, son of Hernan Ruiz I, to be laid to rest with his father was thus fulfilled. Today, therefore, it is possible to corroborate Nieto Cumplido's hypothesis about the burial place of the master builder. The investigation carried out by Enrique Romero de Torres, the interest of the cathedral chapter in granting his request to open the tomb and the intervention by the architect of the Mosque-Cathedral, Felix Hernandez, led us to the exact place.

The year 2047 will mark the 500th anniversary of the death of Hernan Ruiz I. It is important that tribute be paid to this great master who proved capable of adapting his architectural style to the changes that took place during the transition from the fifteenth to the sixteenth century, and ensure that the spirit and culture that made Cordoba stand out as the Umayyad capital of Al-Andalus live on. Today we can say that Hernan Ruiz I rests next to his life's work in the transept of the main church of Cordoba.

Funding: This research received no external funding.

Conflicts of Interest: The authors declare no conflict of interest. 


\section{References}

Abad de Rute. 1958. Historia de la Casa de Córdoba. Boletín de la Real Academia de Córdoba 78: 257-92.

Abad de Rute. 1961. Historia de la Casa de Córdoba. Boletín de la Real Academia de Córdoba 82: 356-58.

Amador de los Ríos, José, and Rodrigo Amador de los Ríos y Villalta. 1879. Monumentos latino-bizantinos de Córdoba. Madrid: José Gil Dorregaray (Imp. de Fortanet y Calcografía Nacional).

Ampliato Briones, Antonio Luis, and Pilar Gimena Córdoba. 2014. Pensamiento arquitectónico y criterios gráficos en la modelización de algunos proyectos tardo-góticos de Hernán Ruiz "el Viejo". Virtual Archaeology Review 5: 5-13. [CrossRef]

Banda y Vargas, Antonio de la. 1974. El Arquitecto Andaluz Hernán Ruiz II. Sevilla: Universidad, ISBN 84-600-6023-4. Burke, Peter. 2010. Hibridismo Cultural. Madrid: Akal, ISBN 978-84-460-2993-9.

Casado Alcaide, Juan, and Maria Ángeles Jordano Barbudo. 2010. Mudéjar en la clausura. El convento de Santa Clara de Montilla. El mudéjar en Montilla. Córdoba: Diputación, Montilla: Ayuntamiento, ISBN 978-84-8154-292-9.

Dodds, Jerrilynn D., María Rosa Menocal, and Abigail Krasner Balbale. 2008. The Arts of Intimacy. Christians, Jews, and Muslims in the Making of Castilian Culture. New Haven and London: Yale University Press.

Feliciano, M. Judith, and Leyla Rouhi. 2006. Introduction: Interrogating Iberian frontiers. Medieval Encounters 12: 317-28. [CrossRef]

Feliciano, M. Judith, and J. C. Ruiz Souza. 2017. Al-Andalus and Castile: Art and Identity in the Iberian Peninsula. In Companion to the History of Architecture. Edited by Harry Francis Mallgrave, Alina Payne, Caroline van Eck, Sigrid De Jong, Martin Bressani, Christina Contandriopoulos, David Leatherbarrow and Alexander Eisenschmidt. Hoboken: Wiley-Blackwell. [CrossRef]

Gamero Ruiz, José, Antonio León Lillo, and Maria Eva Lopera Delgado. 1994. Palma monumental. Catálogo histórico-artístico. Palma del Río: Ayuntamiento. D. L.

Gimena Córdoba, Pilar. 2011. Aspectos constructivos y estructurales del proyecto de la catedral gótica de Córdoba obra de Hernán Ruiz «El Viejo». Paper presented at Actas del Séptimo Congreso Nacional de Historia de la Construcción, Santiago de Compostela, Spain, October 26-29; Edited by Santiago Huerta Fernández. vol. 1, pp. 563-72.

Gimena Córdoba, Pilar. 2014. Forma, espacio y estructura en la transición al renacimiento cordobés. Tradición e innovación en la arquitectura de Hernán Ruiz “El Viejo” (h. 1479-1547). Ph.D. thesis, Universidad de Sevilla, Sevilla, Spain.

Gimena Córdoba, Pilar. 2015. Análisis gráfico de cuatro espacios de Hernán Ruiz "el Viejo". Expresión Gráfica Arquitectónica 26: 232-41. [CrossRef]

Gimena Córdoba, Pilar. 2016. Juegos espaciales y estructurales en la obra de Hernán Ruiz “el Viejo”. Las iglesias de San Mateo de Lucena y Santa María de Baena (Córdoba). In 1514: Arquitectos Tardogóticos en la Encrucijada. Edited by Begoña Alonso Ruiz and Juan Clemente Rodríguez Estévez. Sevilla: Universidad, pp. 609-20. ISBN 978-84-472-1799-1.

Jordano Barbudo, María Ángeles. 2002. El Mudéjar en Córdoba. Córdoba: Diputación, ISBN 84-8154-479-5.

Jordano Barbudo, María Ángeles. Forthcoming. El valor de la heráldica en la decoración parietal de época bajomedieval en Córdoba. Paper presented at Actas del Congreso Español de Historiadores del Arte, Burgos, Spain, June 19-22.

Luque, Juan Bernier, Dionisio Ortiz Juárez, Manuel Nieto Cumplido, and Francisco Lara Arrebola. 1981. Catálogo artístico y Monumental de la provincia de Córdoba. Córdoba: Diputación, ISBN 84-500-9057-1.

Moreno Cuadro, Fernando. 2007. El crucero de la catedral de Córdoba. Estudio iconográfico e iconológico. Madrid: Fundación Universitaria Española. Seminario de Arte e Iconografía "Marqués de Lozoya". Cuadernos de Arte e Iconografía 16: 31.

Nieto Cumplido, Manuel. 1982. Informe histórico-artístico sobre la iglesia parroquial de San Juan Bautista de Hinojosa del Duque. Hinojosa del Duque: Parroquia de San Juan Bautista, ISBN 84-300-7514-3.

Nieto Cumplido, Manuel. 1984. Islam y cristianismo in Historia de Córdoba. Córdoba: Monte de Piedad y Caja de Ahorros, ISBN 84-7580-127-7.

Nieto Cumplido, Manuel. 1998. La catedral de Córdoba. Córdoba: Cajasur, ISBN 84-795-9241-9.

Nieto Cumplido, Manuel. Forthcoming a. Documentos para la historia del arte. Unpublished.

Nieto Cumplido, Manuel. Forthcoming b. Corpus Mediaevale Cordubense, t. 3 and Successives. Unpublished. 
Pardo Rodríguez, Arcadio. 1989. La visión del arte español en los viajeros franceses del siglo XIX. Valladolid: Universidad, ISBN 84-7762-078-4.

Rubio Masa, Juan Carlos. 2001. El mecenazgo artístico de la Casa Ducal de Feria. Mérida: Editora Regional de Extremadura.

Ruiz Souza, Juan Carlos. 2006. Capillas reales funerarias catedralicias de Castilla y León. Nuevas hipótesis interpretativas de las catedrales de Sevilla, Córdoba y Toledo. Anuario del Departamento de Teoría e Historia del Arte 18: 19-29.

Sumichrast, F. C. de. 1912. The Travels of Théofile Gautier, t. 1. Boston: Little Brown and Company, Available online: https://archive.org/stream/travelsofthoph01gautuoft/travelsofthoph01gautuoft_djvu.txt (accessed on 15 June 2018).

Urquízar Herrera, Antonio. 2003. La memoria del pasado en la cristianización de la Mezquita de Córdoba durante la Edad del Humanismo. Paper presented at Correspondencia e integración de las artes: $14^{\circ}$ Congreso Nacional de Historia del Arte, Málaga, Spain, September 18-21; Edited by Juan Antonio Sánchez López and Isidro Coloma Martín. vol. 1., pp. 523-31.

Urquízar Herrera, Antonio. 2017. Admiration and Awe. Morisco Buildings and Identity Negotiations in Early Modern Spanish Historiography. Oxford: University Press, ISBN 978-0-19-879745-6.

(C) 2018 by the author. Licensee MDPI, Basel, Switzerland. This article is an open access article distributed under the terms and conditions of the Creative Commons Attribution (CC BY) license (http:/ / creativecommons.org/licenses/by/4.0/). 